\title{
HUBUNGAN INDEKS MASA TUBUH (IMT) DENGAN SIKLUS MENSTRUASI PADA REMAJA KELAS VIII DI SMP NEGERI 2 KUTA UTARA
}

\author{
The Relationship of Body Index (BMI) and The Menstrual Cycle in Adolescent \\ Class VIII in SMA Negeri 2 Kuta Utara
}

\author{
Ni Putu Mitha Aprilia Suantari ${ }^{1}$, Komang Yogi Triana ${ }^{2}$, Claudia Wuri Prihandini ${ }^{3}$, A.A. \\ Ngurah Nara Kusuma ${ }^{4}$ \\ IProgram S1 Keperawatan, STIKES Bina Usada Bali, Indonesia \\ ${ }^{2}$ Program S1 Keperawatan, STIKES Bina Usada Bali, Indonesia \\ ${ }^{3}$ Program S1 Keperawatan, STIKES Bina Usada Bali, Indonesia \\ ${ }^{4}$ Program S1 Keperawatan, STIKES Bina Usada Bali, Indonesia
}

Korespondensi: Ni Putu Mitha Aprilia Suantaridan mitharaflatahugs@gmail.com

\begin{abstract}
ABSTRAK
Latar Belakang: Salah satu perubahan yang terjadi pada remaja putri adalah terjadinya menstruasi. Menstruasi yang terjadi secara berulang dan teratur setiap bulan pada akhirnya akan membentuk suatu siklus menstruasi. Siklus menstruasi yang terjadi pada remaja putri tidak selalu teratur karena sebagian remaja putri mengalami masalah terkait gangguan siklus menstruasi yang salah satu faktor penyebabnya adalah indeks masa tubuh dari remaja tersebut. Tujuan Penelitian: Tujuan dari penelitian ini adalah untuk mengetahui hubungan indeks masa tubuh (IMT) dengan siklus menstruasi pada remaja kelas VIII di SMP Negeri 2 Kuta Utara. Metedologi: Penelitian ini menggunakan metode penelitian kuantitatif dengan desain penelitian descriptive correlation dengan pendekatan cross sectional, dengan jumlah sampel sebanyak 70 orang. Teknik sampling dengan teknik probability sampling yaitu simple random sampling. Instrumen pengumpulan data dengan menggunakan lembar observasi siklus menstruasi, timbangan badan digital dan pengukur tinggi badan. Data dianalisis dengan menggunakan uji spearman rank. Hasil: Hasil penelitian didapatkan 35,7\% responden dengan indeks masa tubuh normal dan 42,9\% mengalami siklus menstruasi normal. Berdasarkan uji hipotesis didapatkan bahwa $\mathrm{p}=0,001$ dan $\mathrm{r}=0,539$ yang menunjukkan bahwa adanya hubungan antara Indeks Masa Tubuh (IMT) dengan Siklus Menstruasi pada Remaja di SMP Negeri 2 Kuta Utara. Kesimpulan: Perawat diharapkan dapat meningkatkan perannya sebagai edukator dalam mengedukasi dan memberikan informasi kepada remaja untuk dapat menjaga status gizi dan juga indeks masa tubuh sehingga siklus menstruasi dapat teratur.
\end{abstract}

Kata Kunci: Indeks Masa Tubuh; Siklus Menstruasi; Remaja Putri.

\section{ABSTRACT}

Background: One of the changes that occur in teenager is menstruation. Menstruation that occurs repeatedly and regularly every month will eventually form a menstrual cycle. Menstrual cycles that occur in adolescent girls are not always regular because some teenage girls experience problems related to menstrual cycle disorders which one of the contributing factors is the body mass 
index of these adolescents. Research Objectives: They aimed to determine the correlation of body mass index (BMI) with the menstrual cycle in adolescents of class VIII at SMP Negeri 2 Kuta Utara. Methodology: This research used quantitative research methods with a descriptive correlation research design with a cross-sectional approach, with a total sample of 70 people. The sampling technique with the probability sampling technique was simple random sampling. Data collection instruments using menstrual cycle observation sheets, digital body scales, and height measurements. Data were analyzed using the Spearman rank test. Result: The results showed $35.7 \%$ of respondents with a normal body mass index and 42.9\% experienced a normal menstrual cycle. Based on the hypothesis test it was found that $p=0.001$ and $r=0.539$ which showed that there was a correlation between Body Mass Index (BMI) and Menstrual Cycle in Teenager at SMP Negeri 2 Kuta Utara. Conclusions: Nurses are expected to increase their role as educators in educating and providing information to adolescents to be able to maintain nutritional status and body mass index so that the menstrual cycle can be regular.

Keywords: Body Mass Index; Menstrual Cycle;, Teenager.

\section{PENDAHULUAN}

Masa remaja merupakan tahap perubahan yang terjadi dari masa anak-anak menuju ke masa dewasa yang mempunyai rentang usia yaitu 10-19 tahun. Pada saat masa remaja, sudah terjadi perubahan secara fisik, kognitif, sosial, dan emosional. Perubahan yang terjadi pada saat masa remaja menandakan bahwa remaja tersebut sudah memasuki masa pubertas yang ditandai dengan terjadinya pematangan organ reproduksi manusia. (World Health Organization (WHO), 2014). Pada remaja perempuan menstruasi terjadi secara berulang dan teratur setiap bulan dan pada akhirnya akan membentuk suatu siklus menstruasi. Siklus menstruasi merupakan waktu dimana dihitung sejak hari pertama menstruasi sampai datangnya menstruasi pada periode berikutnya dan normalnya terjadi yaitu setiap 21-35 hari (Kusmiran, 2011).

Siklus menstruasi yang terjadi pada wanita tidak selamanya teratur karena sebagian remaja putri mengalami masalah terkait dengan gangguan siklus menstruasi. Menurut hasil riset kesehatan dasar (Riskesdas) di Indonesia khususnya Jawa Tengah menunjukkan bahwa siklus menstruasi yang tidak teratur mencapai angka 13,7\%.. Sedangkan penelitian di Bali menunjukkan bahwa $38,5 \%$ wanita mengalami siklus menstruasi yang tidak teratur (Adnyani, 2012). Tingginya pravelensi terhadap gangguan siklus menstruasi disebabkan oleh beberapa faktor seperti aktivitas fisik, stress dan juga status gizi. Status gizi seseorang dapat ditentukan dengan cara melakukan pengukuran indeks masa tubuh. Indeks masa tubuh (IMT).

Memiliki indeks masa tubuh (IMT) yang tinggi maupun rendah dapat mengakibatkan terjadinya gangguan siklus menstruasi di antaranya tidak adanya menstruasi, siklus menstruasi yang tidak teratur maupun terjadinya nyeri saat menstruasi (Samir, Hanan, 2012). Pada penelitian yang dilakukan oleh 
Hupitoyo (2011) sebelumnya disebutkan bahwa ada beberapa faktor yang mempengaruhi siklus menstruasi. Salah satu hormon yang berperan dalam proses menstruasi adalah hormon estrogen. Menurut analisis penyebab lebih panjangnya siklus mentruasi diakibatkan jumlah estrogen yang meningkat dalam darah akibat meningkatnya jumlah lemak tubuh sehingga berat badan berlebih dapat mempengaruhi siklus menstruasi.

Berdasarkan studi pendahuluan yang dilakukan di SMP Negeri 2 Kuta Utara selama satu hari kepada 15 orang siswi dengan menggunakan beberapa pertanyaan dan juga observasi. Pada survei awal dari 15 siswi didapatkan 8 orang siswi mengalami gangguan siklus menstruasi kurang dari 21 hari, 4 orang mengalami siklus menstruasi lebih dari 35 hari dan 3 orang lagi mengalami siklus menstruasi normal dan pada saat dilakukan observasi didapatkan data bahwa 7 orang siswi memiliki IMT kurus, 4 orang memiliki IMT normal dan 4 orang lagi memiliki IMT lebih. Melihat dari latar belakang diatas, peneliti tertarik untuk meneliti "Hubungan Indeks Masa Tubuh (IMT) dengan Siklus Menstruasi pada Remaja Kelas VIII di SMP Negeri 2 Kuta Utara".

\section{TUJUAN PENELITIAN}

Tujuan dari penelitian ini adalah untuk mengetahui hubungan indeks masa tubuh (IMT) dengan siklus menstruasi pada remaja kelas VIII di SMP Negeri 2 Kuta Utara.

\section{METODE PENELITIAN}

Penelitian ini menggunakan desain penelitian descriptive correlation yang dilakukan dengan pendekatan cross sectional. besar sampel yang digunakan adalah 70 orang responden di SMP Negeri 2 Kuta Utara. Dalam penelitian ini penentuan sampel diambil dengan cara menggunakan teknik probability sampling dengan menggunakan suatu teknik yang dinamakan teknik simple random sampling. Instrumen penelitian yang digunakan oleh peneliti yaitu menggunakan lembar observasi siklus menstruasi dan penelitian yang dilakukan selama satu hari yaitu pada tanggal $20 \mathrm{Mei}$ 2020 dan telah dinyatakan laik etik dengan nomor No 072/EA/KEPKBUB-2020. Peneliti melakukan penelitian online dengan menggunakan media Whatsaap dengan membuat grup yang berisikan dari populasi siswa perempuan kelas VIII di SMP Negeri 2 Kuta Utara. Setelah itu peneliti mulai memperkenalkan diri dan menjelaskan dengan calon responden tentang tujuan, manfaat serta hak-hak yang diperoleh oleh responden dari penelitian ini. Peneliti memilih calon responden, calon responden yang dipilih memenuhi kriteria inklusi dan eksklusi. Peneliti meminta kesediaan responden untuk menjadi responden dalam penelitian ini dan akan diminta untuk membaca serta menjawab informed consent dan lembar observasi yang diberikan oleh peneliti secara online. Setelah data terkumpul kemudian dilakukan pengolahan data dan analisa data.

\section{HASIL PENELITIAN}

Tabel 1. Karakteristik Subjek Penelitian Berdasarkan Usia $(n=70)$

\begin{tabular}{cccccc}
\hline $\begin{array}{c}\text { Variabe } \\
1\end{array}$ & $\mathrm{~N}$ & $\begin{array}{c}\text { Rerat } \\
\mathrm{a}\end{array}$ & $\begin{array}{c}\mathrm{Mi} \\
\mathrm{n}\end{array}$ & $\begin{array}{c}\text { Mak } \\
\mathrm{s}\end{array}$ & $\mathrm{SD}$ \\
\hline Usia & 7 & 14,00 & 13 & 16 & 0,53 \\
& 0 & & & & 8 \\
\hline
\end{tabular}


Berdasarkan hasil tabel 5.1 menunjukan bahwa distribusi frekuensi responden berdasarkan usia menunjukkan bahwa rata- rata usia responden adalah 14,00 tahun dengan usia tertinggi yaitu 16 tahun dan terendah 13 tahun.

Tabel 2. Karakteristik Responden Penelitian Berdasarkan Usia Pertama Menstruasi $(n=70)$

\begin{tabular}{cccccc}
\hline $\begin{array}{c}\text { Variabe } \\
\text { l }\end{array}$ & $\mathrm{N}$ & $\begin{array}{c}\text { Rerat } \\
\mathrm{a}\end{array}$ & $\begin{array}{c}\mathrm{Mi} \\
\mathrm{n}\end{array}$ & $\begin{array}{c}\text { Mak } \\
\mathrm{s}\end{array}$ & $\mathrm{SD}$ \\
\hline Usia & 7 & 12,31 & 10 & 14 & 0,88 \\
& 0 & & & & 8 \\
\hline
\end{tabular}

Berdasarkan hasil tabel 5.2 distribusi frekuensi responden berdasarkan usia pertama menstuasi menunjukkan bahwa rata- rata usia menstruasi responden adalah 12,31 tahun dengan usia tertinggi yaitu 14 tahun dan terendah 10 tahun.

Tabel 3. Indeks Masa Tubuh (IMT) dari Remaja di SMP Negeri 2 Kuta

$$
\begin{gathered}
\text { Utara } \\
(\mathrm{n}=70)
\end{gathered}
$$

\begin{tabular}{ccc}
\hline Kategori & Frekuensi & $\begin{array}{c}\text { Persentase } \\
(\%)\end{array}$ \\
\hline Kurus & 23 & 32,9 \\
\hline Normal & 25 & 35,7 \\
\hline Overweight & 4 & 5,7 \\
\hline Obese I & 7 & 10,0 \\
\hline Obese II & 11 & 15,7 \\
\hline Total & 70 & 100 \\
\hline
\end{tabular}

Berdasarkan hasil tabel 5.4 menunjukan bahwa kriteria indeks masa tubuh yang didapatkan pada responden dari rentang kurus sampai obese II dengan mayoritas indeks masa tubuh dengan kriteria normal yaitu sebanyak 25 orang $(35,7 \%)$, sedangkan untuk kriteria dari indeks masa tubuh pada responden yang paling sedikit yaitu overweight sebanyak 4 orang $(5,7 \%)$.
Tabel 4. Siklus Menstruasi Pada Remaja di SMP Negeri 2 Kuta Utara $(n=70)$

\begin{tabular}{ccc}
\hline Kategori & Frekuensi & $\begin{array}{c}\text { Presentase } \\
(\%)\end{array}$ \\
\hline Polimenorea & 24 & 34,3 \\
Normal & 30 & 42,9 \\
Oligomenorea & 16 & 22,9 \\
\hline Total & 70 & 100 \\
\hline
\end{tabular}

Berdasarkan hasil tabel 5.5 menunjukkan bahwa kriteria siklus menstruasi yang dialami oleh responden yaitu dari rentang polimenorea sampai dengan oligomenorea dengan mayoritas siklus menstruasi yang dialami oleh responden yaitu normal sebanyak 30 orang (42,9), sedangkan untuk kriteria siklus menstruasi yang paling sedikit adalah oligomenorea sebanyak 16 orang $(22,9 \%)$.

Tabel 5. Hasil Analisis Hubungan Antara IMT Dengan Siklus Menstruasi Pada Remaja di SMP Negeri 2 Kuta Utara $(n=70)$

\begin{tabular}{lllllll}
\hline $\begin{array}{l}\text { Indeks } \\
\begin{array}{l}\text { Masa } \\
\text { Tubuh }\end{array}\end{array}$ & Poli & $\begin{array}{l}\text { Nor- } \\
\text { mal }\end{array}$ & $\begin{array}{l}\text { Oli- } \\
\text { go }\end{array}$ & $\begin{array}{l}\text { To- } \\
\text { tal }\end{array}$ & $\begin{array}{l}\text { P- } \\
\text { va- } \\
\text { lue }\end{array}$ & $\begin{array}{l}\text { Corre- } \\
\text { lation } \\
\text { Coef. }\end{array}$ \\
\hline Kurus & 9 & 14 & 0 & 23 & 0,0 & 0,539 \\
\hline Normal & 0 & 9 & 16 & 25 & 01 & \\
\hline $\begin{array}{l}\text { Over- } \\
\text { weight }\end{array}$ & 0 & 7 & 0 & 7 & & \\
\hline Obese I & 11 & 0 & 0 & 11 & \\
\hline $\begin{array}{l}\text { Obese } \\
\text { II }\end{array}$ & 4 & 0 & 0 & 4 & \\
\hline Total & 24 & 30 & 16 & 70 & \\
\hline
\end{tabular}

Berdasarkan hasil Tabel 5.6 menunjukkan bahwa nilai correlation coefficient sebesar 0,539 yang berarti antara indeks masa tubuh dengan siklus menstruasi hubungannya adalah sedang yang bernilai positif, menandakan sifat 
hubungan yang searah yang berarti jika semakin tinggi indeks masa tubuh maka siklus menstruasi akan semakin tinggi juga Dari hasil uji statistik didapatkan nilai $p$ value 0,001 yang berarti $<0,05$ sehingga ada hubungan antara Indeks Masa Tubuh (IMT) dengan Siklus Menstruasi pada Remaja di SMP Negeri 2 Kuta Utara.

\section{PEMBAHASAN}

Hasil penelitian mengenai frekuensi IMT pada remaja kelas VIII di SMP Negeri 2 Kuta Utara menunjukkan bahwa frekuensi IMT pada responden mayoritas berada pada kategori normal yaitu sebanyak 25 responden dengan persentase 37,5\%. Dikarenakan saat melakukan penelitian secara online, di dalam lembar observasi terdapat data berat badan dan tinggi badan dan responden dalam penelitian ini mayoritas mempunyai tinggi badan dan berat badan yang normal sehingga hasil dari indeks masa tubuh dari responden mayoritas normal. Hasil dari penelitian ini juga sejalan dengan penelitian yang dilakukan oleh (Febrina, 2016) yang menemukan mayoritas pada responden penelitiannya dalam kategori indeks masa tubuh normal. Hal ini dapat disebabkan karena adanya faktor-faktor yang dapat mempengaruhi indeks masa tubuh remaja. Faktor-faktor tersebut dibagi menjadi dua faktor yakni faktor internal dan faktor eksternal. Faktor internal dapat terdiri dari genetik, asupan makanan dan juga dapat dari suatu penyakit yang diderita oleh seseorang tersebut, sedangkan faktor eksternalnya didapat dari faktor ekonomi, faktor sosial budaya dan faktor pengetahuan tentang gizi.
Siklus menstruasi merupakan salah satu indikator yang menunjukkan salah satu indikator yang dapat dikatakan untuk menunjukkan kesehatan fungsi reproduksi dari seorang perempuan. Salah satu faktor yang dapat mengakibatkan terjadinya gangguan siklus menstruasi yaitu status gizi (Purnama, 2016). Kelebihan serta kekurangan berat badan yang dimiliki oleh seorang remaja dapat mempengaruhi siklus menstruasi yang terjadi. Hasil penelitian mengenai frekuensi siklus menstruasi pada remaja kelas VIII di SMP Negeri 2 Kuta Utara menunjukkan bahwa frekuensi siklus menstruasi pada responden mayoritas berada pada kategori normal yaitu sebanyak 30 responden dengan persentase 42,9\%. Hal ini dikarenakan saat melakukan penelitian, dalam kejelasan penelitian yang disampaikan oleh peneliti responden yang dapat mengikuti penelitian ini adalah responden yang sudah mengalami siklus menstruasi selama dua kali secara berturut-turut sehingga responden dapat menghitung dan menjawab siklus menstruasi yang mereka alami di dalam lembar observasi. Hasil penelitian ini serupa dengan penelitian yang dilakukan oleh Primastuti (2012) tentang hubungan obesitas dengan keteraturan siklus menstruasi juga menunjukkan bahwa mayoritas responden dalam penelitiannya yakni 76 orang memiliki siklus menstruasi normal sebanyak 81,58\%.

Analisis data tentang hubungan indeks masa tubuh dengan siklus menstruasi ini menggunakan alat uji statistik yaitu spearman rank dengan bantuan software computer SPSS 22.0 didapatkan hasil ( $p$ value 
0,001 dan $\mathrm{r}=0,539$ ) yang artinya terdapat hubungan sedang yang bernilai positif yang artinya adalah hubungan antara kedua variabel yaitu indeks masa tubuh dan siklus menstruasi memiliki hubungan yang searah maksud dari hubungan searah yaitu jika variabel indeks masa tubuh meningkat maka variabel siklus menstruasi juga akan meningkat Salah satu hormon yang sangat berpengaruh dalam proses menstruasi adalah hormon estrogen. Menurut analisis penyebab terjadinya siklus menstruasi yang lebih panjang atau biasa disebut dengan oligomenorea adalah karena jumlah estrogen yang meningkat dalam darah akibat meningkatnya jumlah lemak dalam tubuh. Begitu juga sebaliknya penyebab terjadinya siklus menstruasi yang lebih pendek atau biasa disebut polimenorea disebabkan karena jumlah estrogen yang berkurang di dalam darah (Hupitoyo, 2011). Penelitian ini sejalan dengan penelitian yang dilakukan oleh (Adnyani, 2013) tentang hubungan status gizi dengan siklus menstruasi yang terjadi pada remaja kelas $\mathrm{X}$ di SMK PGRI 4 Denpasar yang menyatakan bahwa jika responden memiliki status gizi yang baik maka itu akan berpengaruh pada siklus menstruasi. Pada penelitian yang dilakukan oleh (Primastuti, 2012) juga dikatakan bahwa pada penelitiannya ditemukan obesitas dapat meningkatkan faktor resiko terjadinya ketidakteraturan dalam siklus menstruasi hingga $3,5 x$ lipat.

\section{KESIMPULAN}

Berdasarkan hasil penelitian yang dilakukan tentang hubungan indeks masa tubuh (IMT) dengan siklus menstruasi pada remaja di
SMP Negeri 2 Kuta Utara, maka dapat diambil kesimpulan yaitu Hasil penelitian mengenai indeks masa tubuh menunjukkan bahwa frekuensi remaja kelas VIII mayoritas berada pada kategori normal yaitu sebanyak 25 orang responden $(35,7 \%)$, Hasil penelitian mengenai siklus menstruasi menunjukkan bahwa frekuensi remaja kelas VIII mayoritas mengalami siklus menstruasi normal yaitu sebanyak 30 orang responden $(42,9 \%)$, dan Ada hubungan antara indeks masa tubuh dengan siklus menstruasi pada remaja kelas VIII di SMP Negeri 2 Kuta Utara dengan nilai $p=0,001$ dan terdapat korelasi sedang yang bernilai positif dengan nilai $r=0,539$.

Tenaga kesehatan dalam hal ini yaitu perawat diharapkan dari penelitian ini memiliki implikasi terhadap pelayanan dimana penelitian ini dapat menjadi acuan dan evidence based practice yang kemudian dapat digunakan sebagai media informasi mengenai hubungan antara indeks masa tubuh dengan siklus menstruasi pada remaja. Bagi Pendidikan Keperawatan Penelitian ini dapar dijadikan sumber referensi bagi pendidikan untuk mengembangkan evidence based nursing khususnya untuk pengetahuan mengenai hubungan antara indeks masa tubuh dengan siklus menstruasi pada remaja. Dan bagi peneliti selanjutnya Temuan peneliti dalam penelitian ini dapat menjadi acuan untuk melakukan penelitian serupa dan dapat meneliti salah satu variabel antara indeks masa tubuh maupun siklus menstruasi dengan variabel lain yang saling berhubungan. 
DAFTAR PUSTAKA

Adnyani, N. N. (2012). 'Hubungan Status Gizi dengan Siklus Menstruasi pada remaja putri kelas $\mathrm{X}$ di SMA PGRI 4 DENPASAR. Jurnal Keperawatan. Fakultas Kedokteran Universitas Udayana Bali, 9-18.

Aljadidi, Almutrafi, Bamousa, Alshehri, Alrashidi, A. (2016). The influence of exam stress on menstrual dysfunctions in Saudi Arabia. J Health Edu Res, 11 (4), 14.

Andriana. (2018). Faktor-faktor yang mempengaruhi siklus menstruasi pada mahasiswa di Universitas Pasir Pangarayan. Jurnal Maternity \& Neonatal, 2 (5).

Andriyani. (2012). Siklus Menstruasi. Retrieved from $\mathrm{http} / / \mathrm{www}$.google.com

Ariadi,Silfiren, lipoeto N. (2017). Effect of Nutritional status fat consumption pattern on menstrual cycle of female students in senior high school. Joernal Obstetry, 10 (1), 6-10.

Arisman. (2010). Gizi Dalam Daur Kehidupan Buku Ajar Ilmu Gizi. Jakarta: EGC.

Asrori, Ali. (2012). Psikologi Remaja. Jakarta: PT Bumi Aksara.

Calis, Popat, Dang, K. (2013). Dysmenorrhea.

Candra, Karina. (2017). Hubungan Obesitas Sentral dengan Siklus Menstruasi dan Dysmenorrhea Primer pada Remaja. J. Nutr. Coll, 6, 319325. Retrieved from //media.neliti.com/media/pub lications/200466-hubungan- obesitas-sentral-dengan-

siklus.pdf

Depkes RI. (2013). Riset Kesehatan

Dasar. Jakarta: Badan

Penelitian dan

Pengembangan Kesehatan

Kementrian Kesehatan RI.

Dieny. (2014). Permasalahan Gizi Pada Remaja Putri. Graha Ilmu.

Febrina. (2016). Hubungan Status Gizi dengan Keteraturan Siklus Menstruasi pada Siswi Remaja di SMAN 12 Padang tahun 2015. Jurnal Kesehatan Masyarakat, 7(2), 35-44.

Felicia. (2015). Hubungan status gizi dengan siklus menstruasi pada remaja putri di PSIK FK universitas sam ratulangi manado. Joernal Keperawatan (e-Kp), Volume 3.

Fitria. (2016). Hubungan Tingkat Stress Dengan Siklus Menstruasi Pada Guru dan Karyawan SMP Negeri 18 Surakarta. 3, 2407-2656.

Hossam, Nadia, Nahed, T. (2016). The relationship between menstrual cycle irregularity and body mass index among secondary schools pupils. IOSR Journal of Nursing and Health Science, 5(1), 48-52.

Hupitoyo. (2011). Obesitas dan Infertilitas. Bumi Kisara.

Hurlock, E. B. (2011). Psikologi Perkembangan. Suatu pendekatan sepanjang rentang kehidupan. Jakarta: Erlangga.

Ismael, S. dan. (2014). Dasar-dasar Metodologi Penelitian. Jakarta: Sagung Seto.

Kusmiran, Eny. (2011). Kesehatan Reproduksi Remaja Dan Wanita. Jakarta: Salemba 
Medika.

Kusmiran, E. (2014). Kesehatan Remaja dan Wanita. Jakarta: Salemba Medika.

Murni. (2015). Hubungan obesitas dengan kejadian gangguan siklus menstruasi pada perempuan dewasa awal di wilayah rw 03 kelurahan ujung menteng kecamatan cakung jakarta timur tahun 2015.

Notoatmodjo, S. (2010). Metode penelitian kesehatan. Jakarta: Rineka cipta.

Nursalam. (2013). konsep dan penerapan metodologi penelitian ilmu keperawatan. Jakarta: Salemba Medika.

Nursalam. (2016). Metodologi penelitian ilmu keperawatan, jakarta. Jakarta: Salemba Medika.

Prawihardjo, S. (2014). Ilmu Kebidanan. Jakarta: Bina Pustaka.

Primastuti. (2012). Hubungan Obesitas Dengan

Ketidakteraturan Siklus Menstruasi.

Purnama. (2016). Hubungan Indeks Massa Tubuh Dengan Lama Siklus Menstruasi Pada Mahasiswi Angkatan 2016 Fakultas Kedokteran Universitas Lampung Relationship Of Body Mass Index With The Length Menstrual Cycle At Student Class Of 2016 Faculty Of Medicine , University Of Lam. Majority, 7(6), 1-7.

Rakhmawati. (2012). Hubungan obesitas dengan kejadian Gangguan siklus menstruasi pada wanita dewasa muda. Retrieved from eprints.undip.ac.id.
Riset Kesehatan Dasar. (2013). Prevalensi Obesitas Kelompok Remaja. Jakarta: Kementerian Kesehatan.

Samir, Hanan, E. (2012). The correlation between body mass index and menstrual profile among nursing students of Ain Shams University.

Sarwono, S. (2011). Psikologi Remaja. Jakarta: PT. Rajagrafindo Persada.

Setiadi. (2013). Konsep Dan Praktik Penulisan Riset Keperawatan. Yogyakarta: Graha Ilmu.

Sherwood. (2011). Fisiologi Reproduksi Wanita. Jakarta: EGC.

Sibagariang. (2013). Gizi Dalam Kesehatan Reproduksi. TIM.

Sugiyono. (2012). Metode penelitian kuantitatif kualitatif R \& D. Bandung: Alfabeta.

Sugiyono. (2014). Statistik untuk penelitian. Bandung: Alfabeta.

Sugiyono. (2016). Metode penelitian kuantitafif, kualitatif dan R\&D. Bandung: Alfabeta.

Supariasa, Bakri Bachyar, F. I. (2012). Indeks Masa Tubuh dalam Penilaian Status Gizi. Jakarta: EGC.

Supariasa, Bakri Bachyar, F. I. (2014). Penilaian Status Gizi. Jakarta: EGC.

Thapa, S. (2015). Relationship Between Body Mass Index and Menstrual Iregularities Among The Adolencents. Journal Of Nursing Research and Practice, 2 (2), 7-11.

Utama, Nugroho. (2014). Masalah Kesehatan Reproduksi Wanita. Yogyakarta: Nuha Medika.

Waryana. (2010). Gizi Reproduksi. 
Ni Putu Mitha Aprilia Suantari: Hubungan Indeks Masa Tubuh (IMT) dengan Siklus Menstruasi pada Remaja Kelas VIII di SMP Negeri 2 Kuta Utara

Yogyakarta: Pustaka Rihama.

World Health Organization (WHO). (2011). Obesity.
World Health Organization (WHO). (2014). Health for the World's Adolescent 